\title{
AKTIVITAS AKTINOMISETES DARI BANGKA-BELITUNG KOLEKSI BIDANG MIKROBIOLOGI, PUSLIT BIOLOGI- LIPI DALAM MEMPRODUKSI ENZIM KITINASE
}

\author{
Yati Sudaryati Soeka, Evi Triana dan Ninu Setianingrum \\ Peneliti di Bidang Mikrobiologi, Puslit Biologi- LIPI, Cibinong \\ e-mail: ceuceu_lipi@yahoo.com
}

\begin{abstract}
The aim of the research was to know the capability of actinomycetes isolate from Bangka Belitung, which stored at Microbiology-LIPI Culture Collection, in producing chitinase enzyme. This isolate which could produce chitinolitic enzyme, signed by clear zone at medium contain 1\% chitine. The chitinase activity of the isolate which incubated for 1-7 days in the room temperature was analyzed by spectrophotometer in $\lambda 584 \mathrm{~nm}$. The result of this experiment was highest chitinase activities with incubated for 3 days, were 1.66 . 10-2 $\mathrm{U} / \mathrm{ml}$. Maximum chitinase activities was found at $1 \%$ starch soluble substrate $2.83 \cdot 10^{-2}, \mathrm{pH} 8.0$ and at $50^{\circ} \mathrm{C}$ condition were $9.3 .10^{-2}$ and 12.98 . $10^{-2} \mathrm{U} / \mathrm{m} /$ respectively.
\end{abstract}

Key words : chitinase, clear zone, spectrophotometer

\section{PENDAHULUAN}

\subsection{Latar Belakang}

Aktinomisetes adalah mikroorganisme atau mikroba kelompok bakteri gram positif yang memiliki rentang distribusi yang luas di alam. Mikroba ini dapat hidup hampir di semua kondisi lingkungan, yaitu terdapat pada substrat seperti tanah, kulit kayu, daun, air, sedimen dasar laut, lumpur, serasah dan padang pasir. Populasi dan jenis Aktinomisetes terbanyak dijumpai di tanah, sehingga Aktinomisetes dianggap sebagai bakteri tanah. Dalam 1 gram tanah subur yang kaya akan unsur diperkirakan terdapat 1 juta lebih populasi Aktinomisetes . Bakteri tersebut memegang peran penting dalam proses biodegradasi senyawa polimer dan memobilisasi unsur hara makro dan mikro, sehingga berperan sentral dalam menjaga kestabilan ekosistem ${ }^{1}$. Uniknya aktinomisetes merupakan bakteri yang paling cerdas dengan ukuran otak (genom atau DNA (deoxyribonucleic acid) dua kali lebih besar dibandingkan dengan bakteri lainnya. Bila berbagai krisis menimpa tanah dalam ujud ketersediaan pangan dan unsure hara lain sangat rendah, maka tidak ada kelompok selain aktinimisetes yang bisa bertahan untuk menyelamatkan komunitas dari kondisi yang sulit tersebut ${ }^{2}$.

Enzim kitinase dapat menghidrolisis kitin menjadi oligomer dan atau monomermonomernya.

Kitin tersedia berlimpah di alam dan merupakan polimer kedua terbanyak setelah selulosa. Industri perikanan paling banyak memberikan sumbangan untuk kelimpahan kitin melalui limbah perikanannya seperti 
udang, kepiting, cumi-cumi, tiram dan lainlain. Banyak hewan dan mikroorganisme menjadi penyumbang ketersediaan kitin di dalam tanah ${ }^{3)}$.

Enzim kitinase disintesa oleh berbagai tanaman, bakteri, jamur dan organisme laut ${ }^{4}$. Pemanfaatan mikroba untuk memproduksi enzim memiliki beberapa kelebihan dibandingkan dengan menggunakan tanaman atau hewan. Dengan dasar pertimbangan tersebut maka perlu dilakukan isolasi mikroba dari alam yang dapat menghasilkan enzim kitinase. Akhir-akhir ini penggunaan kitin dan kitinase di bidang bioindustri sangat menarik perhatian. Kitin dan senyawa turunannya serta kitooligomer yang dihasilkan banyak digunakan dibidang industri kesehatan dan kosmetika ${ }^{5,6,7)}$.

Untuk biodegradasi kitin secara sempurna perlu kerjasama antara beberapa hidrolitik enzim. Kombinasi antara endokitinase dan eksokitinase menghasilkan polimer kitin berupa "soluble $\mathrm{N}$ - asetilglukosamin" ${ }^{8)}$.

\subsection{Tujuan}

Penelitian ini bertujuan untuk mendapatkan isolat unggul aktinomisetes penghasil kitinase koleksi LIPI-MC mengingat kebutuhan industri yang sangat besar.

\section{METODE PENELITIAN}

\subsection{Bahan}

Isolat yang digunakan dalam penelitian ini adalah isolat aktinomisetes koleksi Bidang Mikrobiologi, Puslit Biologi-LIPI, Cibinong. Isolat tersebut diisolasi dari tanah Bangka Belitung.

\subsection{Media Seleksi}

Isolat tersebut dipelihara dalam media kitin agar miring (koloidal kitin 1\%, polypepton $0,1 \%, \mathrm{KH}_{2} \mathrm{PO}_{4} 0,1 \%$, MgSO $4.7 \mathrm{H}_{2} \mathrm{O} 0,05 \%$, agar $2 \%$ ) dan media ini digunakan juga untuk menyeleksi bakteri murni yang dapat merombak kitin dalam petri dish. Inkubasi dilakukan pada suhu kamar selama 3 hari. Hasil pengujian secara kualitatif menunjukkan bahwa isolat yang memiliki aktivitas kitinase ditandai dengan adanya zona bening disekitar koloni. Hasil bagi antara diameter zona bening dan diameter koloni dinyatakan sebagai kekuatan enzim secara nisbi.

\subsection{Metode}

\section{Produksi Kitinase}

Produksi inokulum dilakukan dengan cara isolat ditumbuhkan pada media kitin agar miring, diinkubasi pada suhu kamar sampai berumur 3 hari. Selanjutnya ditambahkan akuades steril. Suspensi mikroba bakteri diukur kerapatan optiknya (OD) dengan spektrofotometer pada $\lambda 600 \mathrm{~nm}$ sampai OD mencapai 0,5.

Produksi kitinase dilakukan dengan menginokulasikan inokulum ke dalam $25 \mathrm{ml}$ media produksi (koloidal kitin 1\%, polypepton $0,1 \%, \mathrm{KH}_{2} \mathrm{PO}_{4} 0,1 \%, \mathrm{MgSO}_{4}$. $7 \mathrm{H}_{2} \mathrm{O} 0,05 \%$ ) dengan $\mathrm{pH} 7$ dan diinkubasi pada suhu kamar selama 1-7 hari di atas pengocok (shaker) dengan kecepatan 120 rpm. Setiap hari dilakukan pengambilan sampel sebanyak $2 \mathrm{ml}$ dan dipisahkan filtrat dan endapannya, disentrifugasi dengan kecepatan 8000 rpm selama 5 menit. Filtrat digunakan sebagai larutan enzim dan diuji aktivitas kitinasenya.

\section{Media Kultur Bakteri}

Isolat yang menghasilkan aktivitas kitinase tertinggi dengan waktu inkubasi tertentu dipakai dalam perlakuan selanjutnya. Inokulasikan mikroba dalam bentuk kultur dipipet sebanyak 0,5 ml masing-masing dimasukkan ke dalam $25 \mathrm{ml}$ media cair kitin 1\% dengan variasi $\mathrm{pH}$ bufer (pH 3-9). Larutan bufer yang digunakan adalah 0,05 M bufer asetat ( $\mathrm{pH} 3,4,5), 0,05 \mathrm{M}$ bufer fosfat $(\mathrm{pH} \mathrm{6,7)}$ dan $0,05 \mathrm{M}$ bufer tris- $\mathrm{HCl}$ 
(pH 8, 8,5, 9).

\section{Pengujian Aktivitas Kitinase}

Aktivitas kitinase diuji dengan mengukur kadar gula amino sebagai produk hidrolisis kitin oleh kitinase. Konsentrasi gula amino diukur menggunakan Metode Reissig (1955). Senyawa $N$-asetil glukosamin (GlcNAc) digunakan sebagai standar untuk penghitungan aktivitas kitinase. Satu unit kitinase adalah banyaknya enzim yang dapat menghasilkan $1 \mu \mathrm{mol} N$-asetil glukosamin dari substrat koloidal kitin per menit pada suhu $50^{\circ} \mathrm{C}, \mathrm{pH} 7,0$. Larutan kitinase yang menghasilkan GlcNAc terlalu tinggi diencerkan terlebih dahulu dan faktor pengenceran digunakan dalam perhitungan aktivitasnya.

Sebanyak $0,5 \mathrm{ml}$ larutan enzim direaksikan dengan $0,5 \mathrm{ml}$ substrat $1 \%$ koloidal kitin dengan $\mathrm{pH} 7$ dan diinkubasi pada suhu $50^{\circ} \mathrm{C}$ selama 30 menit. Reaksi enzimatis dihentikan dengan memasukkan campuran ke dalam air mendidih selama 5 menit. Selanjutnya disentrifugasi dengan kecepatan 8000 rpm selama 5 menit dan filtrat dipisahkan dari endapan. Sebanyak 250 $\mu \mathrm{l}$ filtrat ditambah $50 \mu \mathrm{l}$ potasium tetraborat, dididihkan selama 3 menit dan didinginkan dengan segera. Ditambahkan 1,25 ml reagen 4-(dimetil amino)benzaldehida (DMAB), diinkubasi pada suhu $37^{\circ} \mathrm{C}$ selama 20 menit dan OD dibaca dengan spektrofotometer pada $\lambda 584 \mathrm{~nm}^{10)}$.

\section{Karakterisasi kitinase kasar terhadap konsentrasi substrat kitin, $\mathrm{pH}$, suhu dan waktu inkubasi enzim.}

Pengaruh konsentrasi substrat kitin pada waktu analisa diuji dengan konsentrasi $0,05-1,5 \%$. Pengaruh $\mathrm{pH}$ terhadap aktivitas kitinase diuji dengan cara mereaksikan larutan enzim dengan substrat kitinase dengan konsentrasi yang tertinggi aktivitasnya dengan berbagai variasi bufer dengan $\mathrm{pH}$ 3-9 dengan interval 1. Pengaruh suhu terhadap aktivitas enzim diuji dengan cara mereaksikan larutan enzim dengan substrat kitinase dengan konsentrasi yang tertinggi aktivitasnya dalam $\mathrm{pH}$ bufer dengan aktivitas kitinase tertinggi yaitu pada suhu 30$70^{\circ} \mathrm{C}$ dengan interval $10^{\circ} \mathrm{C}$. Pengaruh waktu inkubasi diuji dengan cara mereaksikan larutan enzim dengan konsentrasi substrat kitinase, $\mathrm{pH}$,dan suhu dengan aktivitasnya yang tertinggi dan waktu inkubasi 5- 35 menit dengan interval 5 menit.

\section{HASIL DAN PEMBAHASAN}

\section{Hasil}

Secara kualitatif dilakukan menurut metoda Jeuniaux, 1966. Seleksi didasarkan pada kemampuan aktinomisetes dalam menghidrolisis kitin (polimer rantai panjang) menjadi rantai-rantai pendek atau monomernya. Adanya aktivitas kitinase ditandai dengan adanya zona bening di sekitar koloni. Kemampuan dari isolat bervariasi sesuai dengan isolatnya. Dilaporkan dengan menggunakan media selektif ini sekitar $85 \%$ dari aktinomisetes yang terisolasi memperlihatkan adanya zona bening di sekitar koloni (Gambar 1).

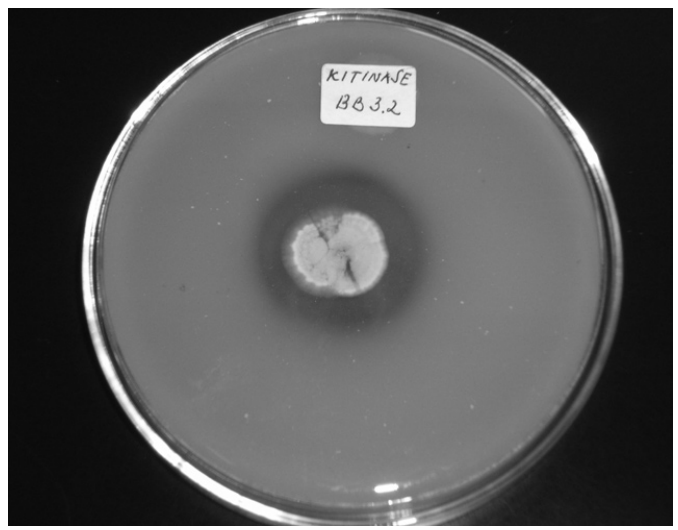

Gambar 1. Zona bening dari BB 3.2

Pada gambar 2 aktivitas kitinase ditunjukkan dalam nilai kerapatan optik (OD) diukur dengan spektrofotometer pada $\lambda 584 \mathrm{~nm}$. BB 3.2 didapat setelah diinkubasi selama 3 hari adalah sebesar 0,374 . Isolat 
yang diuji secara kuantitatif mempunyai kemampuan mendegradasi kitin, pada hari pertama isolat sudah tumbuh dengan baik dan telah menggunakan sebagian besar koloidal kitin yang tersedia dalam media produksi (terlihat dari kejernihan filtrat). Kitin yang tersedia dalam media produksi sudah digunakan baik untuk pertumbuhan ataupun untuk aktivitas lainnya.

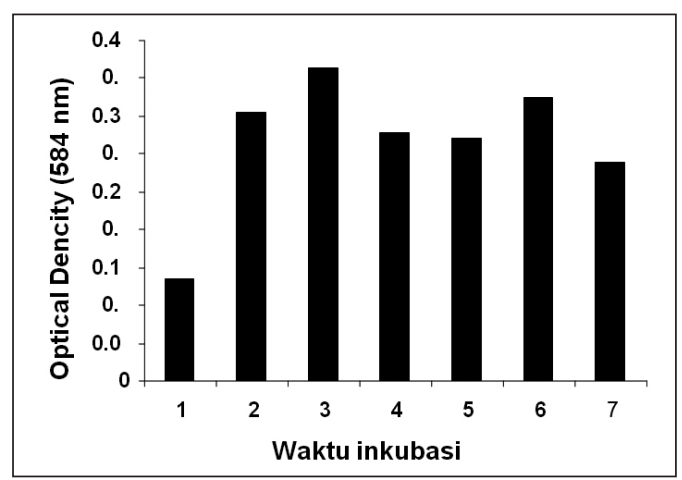

Gambar 2. Kerapatan optik (OD) dengan waktu inkubasi 1-7 hari

Pada gambar 3 dapat dilihat aktivitas kitinase dalam satuan Unit/ml didapat aktivitas tertinggi sebesar 1,66 $\cdot 10^{-2} \mathrm{U} / \mathrm{ml}$ setelah inkubasi selama 3 hari. Enzim yang diukur aktivitasnya adalah enzim kasar setelah dihitung dengan menggunakan kurva standar dengan menggunakan $\mathrm{N}$-acetyl D-glucosamine. Inkubasi dilakukan di atas alat pengocok dengan kecepatan $120 \mathrm{rpm}$ pada suhu ruang selama 1-7 hari.

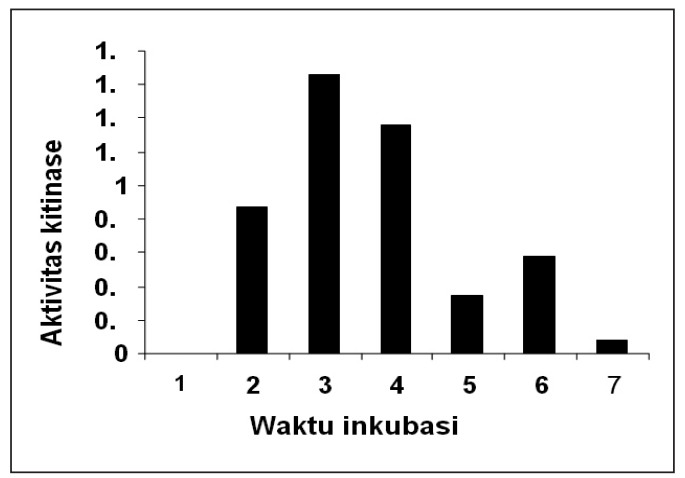

Gambar 2. Aktivitas kitinase dengan waktu inkubasi 1-7 hari
Pada gambar 4 diperlihatkan konsentrasi substrat kitin yang digunakan pada waktu analisa media produksi. Dengan konsentrasi mulai 0,05 sampai $1,75 \%$ dan aktivitas tertinggi di dapat dari substrat pati terlarut dengan konsentrasi $1 \%$ sebesar 2,8 . $10^{-2} \mathrm{U} / \mathrm{ml}$

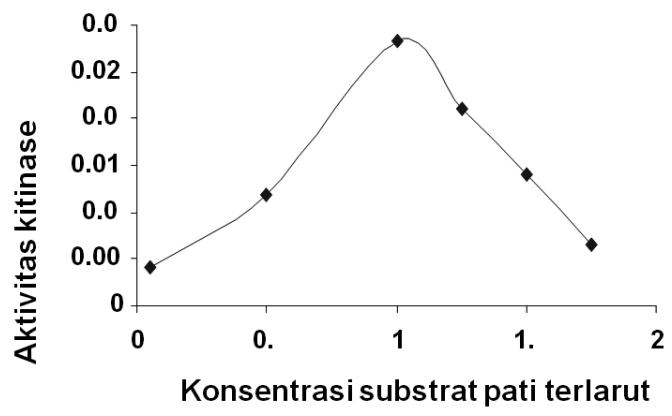

Gambar 4. Aktivitas kitinase dengan berbagai konsentrasi kitin (\%)

Perlakuan selanjutnya isolat BB 3.2 diukur aktivitasnya dalam substrat kitinase $1 \%$ dengan variasi $\mathrm{pH}$ bufer 3-9 hasilnya ditunjukkan pada gambar 5. Data dari gambar 4 menunjukkan bahwa aktivitas kitinase isolat tertinggi pada reaksi enzimatis pada $\mathrm{pH} 8$ dengan substrat kitin $1 \%$ didapat $9,3 \cdot 10^{-2} \mathrm{U} / \mathrm{ml}$.

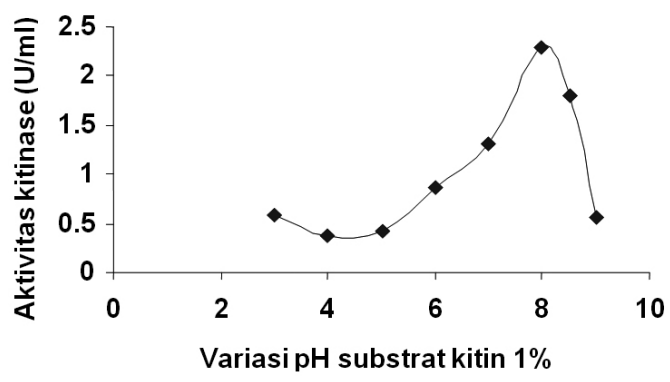

Gambar 5. Aktivitas kitinase dengan variasi $\mathrm{pH}$ substrat 3-9

Dan pengaruh suhu terhadap aktivitas kitinase hasilnya ditunjukkan pada gambar 6 .

Dapat dilihat isolat yang mempunyai aktivitas tertinggi pada suhu $50^{\circ} \mathrm{C}$ dengan $\mathrm{pH}$ 8 dengan substrat kitin $1 \%$ sebesar 12,98. 10 $-2 \mathrm{U} / \mathrm{ml}$. Laju reaksi enzim meningkat sampai 


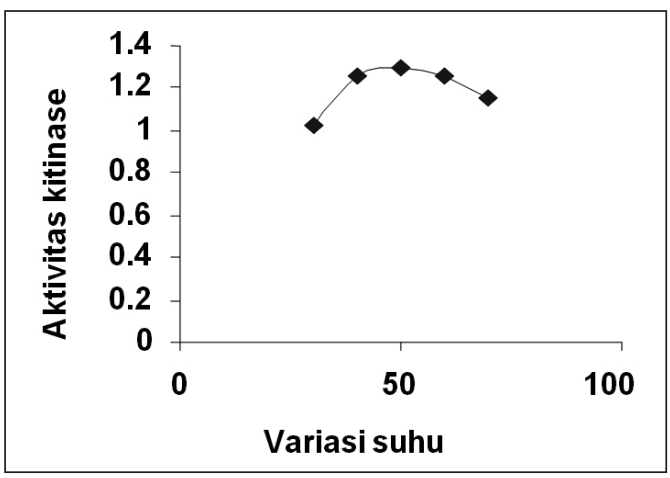

Gambar 6. Aktivitas kitinase dengan variasi suhu 30- $70^{\circ} \mathrm{C}$

suhu optimum kemudian berkurang sampai suhu maksimum tercapai.

\subsection{Pembahasan}

Isolat BB 3.2 adalah marga Nocardia termasuk yang dominan di dalam tanah dan termasuk kelompok rare Aktinomisetes yaitu kelompok yang jarang atau sulit ditemukan Nocardia secara umum sebagai bakteri tanah yang bersifat obligat aerob dan memiliki kemampuan memanfaatkan hidrokarbon sebagai sumber energinya ${ }^{1}$. Menurut $\mathrm{Hsu}^{11)}$ media agar kitin adalah media selektif yang sering digunakan untuk mengisolasi aktinomisetes yang terdapat pada tanah dan air. Konsentrasi koloidal kitin yang digunakan untuk skrining aktinomisetes dengan memperlihatkan zona bening yang jelas di sekitar koloni biasanya mengandung sekitar $1 \%$ koloidal kitin. Zona bening paling jelas terlihat pada media agar kitin yang mengandung $0,4 \%$ koloidal kitin, pada konsentrasi koloidal kitin yang lebih rendah $(0,1-0,2 \%)$ tidak ada penampakan zona bening dan pada konsentrasi yang lebih tinggi atau $1-2 \%$ zona bening yang dihasilkan terlihat agak kabur. Monreal ${ }^{12}$ menggunakan agar kitin dengan "double layer" untuk skrining bakteri penghasil kitinase, dan pada lapisan bawah digunakan media mengandung $0,5 \%$ yeast ekstrak dan $2 \%$ agar dan yang bagian atas media mengandung $1 \%$ koloidal kitin. Secara keseluruhan seleksi secara kualitatif isolat aktinomisetes penghasil kitinase yang dilakukan dalam penelitian ini menunjukkan hasil yang baik dan jelas. Untuk pengujian secara kuantitatif masih ada beberapa kendala dan masih perlu diteliti lebih lanjut. Beberapa isolat yang secara kualitatif mempunyai nilai aktivitas relatif tinggi tetapi secara kuantitatif aktivitas yang dihasilkan masih lebih rendah dari isolat yang mempunyai aktivitas relatifnya yang lebih tinggi. Dari beberapa penelitian mengenai kitinase yang telah dilakukan, hasil tersebut dilaporkan bahwa enzim kitinase cukup kompleks dan berdasarkan sifat-sifat hidrolisis enzimatis kitin secara lengkap menjadi $\mathrm{N}$-asetil glukosamin dilakukan melalui sisitem kitinolitik $0^{13)}$ Dalam lintasan degradasinya, kitin mempunyai 2 alternatif. Lintasan pertama yang menghidrolisis ikatan ß1-4, disebut proses kitinolitik, melibatkan dua jenis enzim yaitu endokitinase (EC 3.2.1.14) dan eksokitinase atau kitobiosidase. Endokitinase yang memotong rantai kitin secara acak pada sisi dalam, menghasilkan multimer dengan berat molekul rendah dari $\mathrm{N}$-asetilglukosamin yang dapat larut seperti kitotetraosa, kitotriosa dan dimer diasetil kitobiosa. Eksokitinase dapat dibagi menjadi dua sub kategori: kitobiosidase (EC 3.2.1.29) yang mengkatalisa pemotongan diasetilkitobiosa dimulai dari ujung non pereduksi pada mikrofibrilkitin dan 1-4ß-N-asetilglukosaminidase (EC 3.2.1.30) yang memotong produk-produk oligomer dari endokitinase dan kitobiosidase menghasilkan monomer $\mathrm{N}$-asetilglukosamin ${ }^{4}$. Diasetilkitobiosa sebagai hasil utama yang kemudian didegradasi oleh eksokitobiosidase menjadi monosakarida dan disakarida. Bentuk monosakarida dan disakarida akan diangkut ke dalam mikroorganisme dan berfungsi sebagai sumber karbon dan nitrogen. Suatu molekul substrat berikatan dengan bagian aktif enzim melalui suatu mekanisme khas dan kolektif dalam hubungan yang disebut lock- and-key. Sebagian enzim mempunyai kekhususan yang mutlak terhadap susbtrat dan tidak 
akan menyerang substrat lain meskipun strukturnya hamper sama. Sebagian lainnya mempunyai kekhususan yang kurang dan dapat bereaksi dengan suatu golongan, substrat tertentu atau kelompok molekul sejenis ${ }^{15}$.

Setiap enzim mempunyai pH optimum yaitu kisaran $\mathrm{pH}$ dimana enzim menunjukkan aktivitas maksimum dengan stabilitas yang tinggi. Mikroba yang hidup di alam tersebar luas mulai yang hidup di daerah asam sampai dengan alkali, dari suhu rendah sampai suhu tinggi ${ }^{16)}$. Dan menurut Palmer ${ }^{17}$ setiap enzim mempunyai karakteristik $\mathrm{pH}$ optimum dan enzim tersebut aktif pada kisaran $\mathrm{pH}$ yang relatif sempit. Penentuan $\mathrm{pH}$ optimum bertujuan untuk mengetahui kondisi optimum aktivitas enzim sehingga penggunaan enzim dapat disesuaikan dengan karakteristiknya tersebut sehingga pada saat digunakan dapat diperoleh aktivitas enzim yang maksimal. Menurut Chaplin dan Bucke ${ }^{17)}$ pada larutan alkali ( $\mathrm{pH}$ di atas 8 ) mungkin akan terjadi kerusakan pada residu sistin, sedangkan pada larutan asam ( $\mathrm{pH}$ kurang dari 4) hidrolisis dari ikatan peptida yang tidak stabil dapat terjadi di samping residu asam aspartat.

Berdasarkan suhu pertumbuhannya mikroba digolongkan menjadi lima kelompok yaitu psikrofil tumbuh pada suhu $-5-20^{\circ} \mathrm{C}$, mesofil suhu $20-45^{\circ} \mathrm{C}$, termofil $45-65^{\circ} \mathrm{C}$, termofil ekstrim $65-85^{\circ} \mathrm{C}$ dan hipertermofil $85-100^{\circ} \mathrm{C}^{18)}$. Menurunnya aktivitas mengikuti meningkatnya suhu di atas optimum biasanya disebabkan oleh perusakan enzim ${ }^{16}$.

Menurut Palmer ${ }^{17)}$ kecepatan reaksi kimia akan meningkat dengan meningkatnya suhu karena akan mempercepat gerak termal molekul dan karenanya akan meningkatkan bagian molekul yang memiliki energi dalam dengan jumlah yang cukup untuk memasuki keadaan transisi. Aktivitas enzim juga akan meningkat dengan meningkatnya suhu sampai suhu optimumnya, tetapi setelah melewati suhu optimumnya aktivitas enzim akan menurun.

\section{KESIMPULAN}

Isolat BB 3.2 adalah marga Nocardia termasuk kelompok rare Aktinomisetes yaitu kelompok yang jarang atau sulit ditemukan. Positif mempunyai aktivitas kitinase dengan nilai relatif dengan ditandai dengan adanya daerah bening disekitar isolatnya, mempunyai aktivitas kitinase tertinggi didapat dengan waktu inkubasi 3 hari sebesar 1,66 . $10^{-2} \mathrm{U} / \mathrm{ml}$. Aktivitas kitinase maksimal didapat pada konsentrasi substrat $1 \%$ sebesar $2,83 \cdot 10^{-2} \mathrm{U} / \mathrm{ml}$. Pada $\mathrm{pH} 8,0$ dan suhu $50^{\circ} \mathrm{C}$ masing-masing 9,3 . $10^{-2}$ dan $12,98 \cdot 10^{-2} \mathrm{U} / \mathrm{ml}$

\section{DAFTAR PUSAKA}

1. Madigan, M.T., J.M. Martiko and J. Parker. 2003. Biology of Microorganisms. Dalam Nurkanto A., Rahmansyah M., Kanti A. Teknik Isolasi Aktinomisetes. Pusat Penelitian Biologi-LIPI Cibinong Science Center. LIPI Press.

\section{Indobic-++ Indobic-Indonesia Biotechnology Information Center 22/01/2010}

3. Yurnaliza, 2008. Senyawa Khitin dan Kajian Aktivitas Enzim Mikrobial Pendegradasinya. Digitized by USU digital library. 11/24/2008.

4. Kupiec RC. dan Ilan C. 1998. The Molecular Biology of Chitin Degradation Current opinion in Biotech. 9:270-277.

5. Majeti NV, R Kumar. 2000. A review of chitin and chitosan applications. Reactive \& Functional Polymers. 46, 1-27.

6. Terayama H, S Takahashi, H Kuzuhara. 1993. Large-scale preparation of $\mathrm{N}, \mathrm{N}$-diacetylchitobiose by enzymic degradation of chitin and its chemical modification. J. Carbohydr. Chem. 12, 81-93. 
7. Kobayashi S, T Kiyosada, S Shoda. 1997. A novel method for síntesis of chitobiose via enzymatic glycosylation using sugar oxazoline as glycosyl donor. Tetrahedron Lett., 38, 21112112.

8. Gkargkas K, D Mamma, G Nedev, E Topakas, P Christakopoulos, D Kekos and Marcis BJ. 2004. Studies on $\mathrm{N}$-acetyl-D-glucosaminidase produced by Fusarium oxysporum F3 grown in solid-state fermentation. Process Biochemistry, vol 39, no. 11, p. 15991605.

9. Reissig JL, JL Strominger and LF Leloir. 1955. A Modified Colorimetric Method for The Estimation of $\mathrm{N}$-acetylamino Sugars. Journal of Biological Chemistry 217, 959-966.

10. Widhyastuti N, 2007. Produksi Kitinase Ekstraseluler Aspergillus rugulosus 501 secara Optimal pada Media Cair. Jurnal Berita Biologi 8(6). Hal 547-553.

11. Jeuniaux C. 1966. Chitinases. In: Neufeld, E.F. and Ginsburg, V. Eds. Complex Carbohydrates. Methods in Enzymology. Academic Press, Inc., New York, vol. 8, pp. 644-650.

12. Hsu SC and Lockwood JL. 1975. Powdered chitin agar as a selective medium for enumeration of actinomycetes in water and soil. Applied Microbiology 29, 422-426.
13. Monreal J and Reese ET. 1968. The Chitinase of Serea marcescens. Can. J. Microbiol. 15: 689-696.

14. Patil RS, Vandona G, dan Mukund VD. 2000. Chitinolytic Enzymes : An Exploration. Enzyme and Microbiol. Tech. 26:473-483.

15. Wirahadikusumah, M, 1989. Biokimia, protein, enzim dan asam nukleat. Edisi-4. Penerbit ITB.

16. Volk WA \& Wheeler MF.1988. Mikrobiologi Dasar. Jilid 1. Soenartono Adisoemarto Editor. Penerbit Erlangga Jakarta. Terjemahan dari: Basic Microbiology, fifth edition.

17. Palmer, T. 1991. Understanding Enzymes. Ellis Horwoood Ltd. England.

18. Chaplin MF dan Bucke C. 1990. Enzyme Technology. Cambridge University Press, Cambridge.

19. Rudiger, A Sunna, A dan Antranikian G. 1994. Enzymes from Extreme Thermophilic and Hyperthermophilic Archea and Bacteria. Di dalam : Carbohydrases, Handbook of Enzyme Catalysis in Organic Synthesis. VCH Verlagsgesellschafft, Weinhem. 